\title{
Type 1 (Insulin-Dependent) Diabetes Mellitus with Coexisting Autoimmune Thyroid Disease in Japan
}

\author{
Nobuhiro Chikuba, Shoichi Akazawa, Yoshihiko Yamaguchi, Eiji Kawasaki, Hirofumi Takino, \\ Yukio Takao, Yasuo Maeda, Shinichiro Okuno, Hidefumi Yamamoto, Atsushi Yokota, \\ Masaaki Yoshimoto* and Shigenobu Nagataki
}

\begin{abstract}
Type 1 diabetes mellitus is known to be a heterogenous disease which is frequently complicated with other autoimmune thyroid diseases (AITD). The present study was designed to investigate the clinical characteristics and HLA antigens in Japanese Type 1 diabetic patients with AITD. Subjects were 25 Type 1 diabetic patients with AITD (13 Graves' disease and 12 Hashimoto's thyroiditis) and 32 Type 1 diabetic patients without AITD. Compared with Type 1 diabetic patients without AITD, age at onset of diabetes was later and positive ICA persisted much longer in the diabetic patients with AITD. Compared with normal controls, DR9 was increased in the patients with AITD, while DR4 was increased in those without AITD. Type 1 diabetic patients with AITD were characterized by the late onset of diabetes, persistent ICA and increased association with DR9. These results suggest that immunological and genetic heterogeneity may exist within Japanese Type 1 diabetic patients.
\end{abstract}

(Internal Medicine 31: 1076-1080, 1992)

Key words: HLA-DR9, islet cell antibodies (ICA), heterogeneity

\section{Introduction}

Type 1 (insulin-dependent) diabetes mellitus is an autoimmune and heterogenous disease $(1,2)$ and is frequently complicated with organ-specific autoimmune disease (3). Among autoimmune diseases, thyroid autoimmunity is the most common in Type 1 diabetes mellitus $(4,5)$.

In Japanese patients, Type 1 diabetes mellitus is closely associated with DR4 (6) and DR9 (7). Immunogenetic features of Type 1 diabetes mellitus in Japanese with autoimmune thyroid disease (AITD) have not been well described. Therefore, the aim of the present study was to analyze the clinical characteristics and HLA antigens in Japanese Type 1 diabetic subjects with coexisting AITD in order to contribute to the understanding of the respective roles of different susceptibility genes controlling these overlapping clinical entities.

\section{Subjects and Methods}

During 1982-1991, 57 patients with Type 1 diabetes mellitus (13-60yrs old, 17 men, 40 women), consisting of 25 patients with AITD and 32 patients without AITD, who were seen in the outpatient Endocrinology and Metabolism clinic of Nagasaki University Hospital were studied. Patients with AITD consisted of 13 patients with Graves' disease and 12 patients with Hashimoto's thyroiditis. The clinical criteria for the selection of patients with Type 1 diabetes mellitus included the occurence of ketoacidosis at onset or a history of having ketosis, daily insulin requirements of $0.7 \mathrm{U} / \mathrm{kg} /$ day and a postprandial serum C-peptide response of lower than $0.3 \mathrm{ng} / \mathrm{ml}$. The diagnosis of Graves' disease was made on the basis of history, signs of thyrotoxicosis with diffuse goiter, elevated serum thyroid hormone concentration, increased thyroidal ${ }^{131}$ I uptake, and unresponsiveness to TRH. The diagnosis of Hashimoto's thyroiditis was based on high titers of anti-thyrogloblin antibody (ATGA) and antithyromicrosomal antibody (ATMA) (>x100 for ATGA, >x6400 for ATMA) with or without goiter. Some of the patients underwent needle biopsy and all of them were asymptomatic. HLA typing for A, B, C and DR loci was done by the standard microcytotoxicity

From the First Department of Internal Medicine and *the Department of Pediatrics, Nagasaki University School of Medicine, Nagasaki Received for publication September 19, 1991; Accepted for publication June 17, 1992

Reprint requests should be addressed to Dr. Shigenobu Nagataki, the First Department of Internal Medicine, Nagasaki University School of Medicine, 7-1 Sakamoto-machi, Nagasaki 852, Japan 
technique (8), using the 9th International Histocompatibility Workshop typing sera or local sera standardized against these sera. The organ-specific autoantibodies and islet cell antibodies (ICA) were measured in all Type 1 diabetic patients; anti-thyroglobulin antibody (ATGA) and anti-thyromicrosome antibody (ATMA) by the haemoagglutination method, antiadrenal antibody (AAA) and antigastric antibody (AGA) by the indirect immunoflurorescence technique. The cutoffs were $x 100$ for ATGA, x400 for ATMA, x40 for AGA, x1 for AAA. The prevalence of ATGA, ATMA, AGA and AAA in the normal Japanese up to 35 years of age were $0 \%(0 / 60)$, $1.7 \%(1 / 60), 1.7 \%(1 / 60)$ and $1 \%(0 / 100)$, respectively. ICA were detected by an immunoenzymatic method which was established in our laboratory (9). Briefly, staining procedures by peroxidase-labeled protein A (POPA) are as follows; fresh frozen sections of human pancreatic tissues (blood type 0) were washed 3 times with phosphate-buffered saline (PBS) containing 2\% bovine serum albumin. Fifty microliters of samples were applied to the pancreatic tissues and incubated in a moist chamber for 1 hour at room temperature. The tissues were mounted and observed under light microscopy.
Positive staining was determined as cytoplasmic staining of the islet cells. When ICA was positive, the patients were followed prospectively with a variable duration of follow-up period. Our laboratory was ranked as (A) in the precision of ICA assay by the third international work shop on the standarization of cytoplasmic islet cell antibodies (ICA). Sensitivity, specificity, validity and consistency were $75 \%, 100 \%, 86 \%$ and $100 \%$, respectively. The statistical tests used were $\chi^{2}$-test and student's t-test. The values are expressed as mean \pm SD. A value of $\mathrm{P}<0.05$ was considered significant.

\section{Results}

The 25 Type 1 diabetic patients with AITD consisted of 12 patients with Hashimoto's thyroiditis and 13 patients with Graves' disease (Table 1). Of 13 Type 1 diabetic patients with Graves' disease, Type 1 diabetes mellitus preceded in 7 patients, while Graves' disease preceded in 6 patients. The mean interval between onset of Type 1 diabetes and insulin administration was $13.5 \pm 2.8$ months.

Table 2 shows the clinical characteristics of Type 1

Table 1. Clinical Features of Type 1 Diabetic Patients with AITD

\begin{tabular}{|c|c|c|c|c|c|c|c|c|c|}
\hline No. & Sex & $\begin{array}{l}\text { Coexisting } \\
\text { Autoimmune } \\
\text { disease }\end{array}$ & $\begin{array}{l}\text { Age at } \\
\text { onset } \\
\text { of } \\
\text { Type } 1 \\
\text { diabetes }\end{array}$ & $\begin{array}{l}\text { Age at } \\
\text { onset } \\
\text { of } \\
\text { AITD }\end{array}$ & $\begin{array}{c}\text { Duration } \\
\text { (year) }\end{array}$ & $\begin{array}{c}\text { Interval } \\
\text { between } \\
\text { onset of } \\
\text { diabetes \& } \\
\text { initial Ins. } \\
\text { Tx (month) }\end{array}$ & $\begin{array}{c}\text { Insulin } \\
\text { requirement } \\
\text { (U/kg/day) }\end{array}$ & $\begin{array}{c}\text { Titer } \\
\text { of } \\
\text { ATMA }\end{array}$ & $\begin{array}{l}\text { ICA at } \\
5 \text { years } \\
\text { diagnosis }\end{array}$ \\
\hline 1. & $\mathbf{F}$ & Hashimoto's & 17 & $\mathrm{H}$ & 9 & 11 & 0.83 & 6,400 & $(+)$ \\
\hline 2. & $\mathrm{~F}$ & Hashimoto's & 3 & $\mathrm{H}$ & 8 & - & 1.23 & 25,600 & $(-)$ \\
\hline 3. & $\mathrm{M}$ & Hashimoto's & 18 & $\mathrm{H}$ & 12 & 0 & 0.40 & 6,400 & $(+)$ \\
\hline 4. & $\mathrm{M}$ & Hashimoto's & 18 & $\mathrm{H}$ & 8 & 0 & 0.41 & 6,400 & $(-)$ \\
\hline 5. & $\mathbf{F}$ & Hashimoto's & 33 & $\mathrm{H}$ & 5 & 0 & 0.50 & 400 & $(+)$ \\
\hline 6. & $\mathbf{F}$ & Hashimoto's & 13 & $\mathrm{H}$ & 16 & 12 & 1.11 & 6,400 & $(-)$ \\
\hline 7. & $F$ & Hashimoto's & 59 & $\mathrm{H}$ & 4 & 18 & 0.32 & 6,400 & ND \\
\hline 8. & $\mathrm{M}$ & Hashimoto's & 35 & $\mathrm{H}$ & 7 & 8 & 0.79 & 102,400 & $(+)$ \\
\hline 9. & M & Hashimoto's & 38 & $\mathrm{H}$ & 0 & 4 & 0.44 & 6,400 & ND \\
\hline 10. & $\mathbf{F}$ & Hashimoto's & 16 & $\mathrm{H}$ & 6 & 1 & 0.63 & 80,000 & $(+)$ \\
\hline 11. & $\hat{F}$ & Hashimoto's & 40 & $\mathrm{H}$ & 13 & 11 & 0.76 & 25,600 & $(+)$ \\
\hline 12. & M & Hashimoto's & 15 & $\mathrm{H}$ & 6 & 12 & 0.86 & 6,400 & $(-)$ \\
\hline 13. & $F$ & Graves' & 10 & 11 & 1 & 3 & 1.05 & 1,600 & ND \\
\hline 14. & $\hat{F}$ & Graves' & 40 & 36 & 7 & 13 & 0.74 & 102,400 & $(+)$ \\
\hline 15. & $\mathrm{~F}$ & Graves' & 47 & 51 & 7 & 0 & 0.52 & 400 & $(+)$ \\
\hline 16. & $\mathrm{~F}$ & Graves' & 43 & 44 & 3 & 32 & 0.30 & 6,400 & $(-)$ \\
\hline 17. & $\mathrm{M}$ & Graves' & 25 & 44 & 24 & 18 & 0.36 & 400 & $(+)$ \\
\hline 18. & $\mathrm{~F}$ & Graves' & 42 & 35 & 4 & 5 & 0.15 & 25,600 & $(+)$ \\
\hline 19. & M & Graves' & 37 & 32 & 6 & 0 & 0.41 & 1,600 & $(+)$ \\
\hline 20. & $\mathrm{~F}$ & Graves' & 11 & 5 & 9 & 12 & 1.11 & 6,400 & $(-)$ \\
\hline 21. & $\mathrm{~F}$ & Graves' & 28 & 24 & 6 & 0 & 0.72 & 1,600 & $(-)$ \\
\hline 22. & M & Graves' & 32 & 34 & 10 & 3 & 0.60 & 25,600 & $(+)$ \\
\hline 23. & M & Graves' & 26 & 14 & 6 & 4 & 0.78 & 6,400 & $(+)$ \\
\hline 24. & $\mathrm{~F}$ & Graves' & 27 & 15 & 7 & - & 1.05 & 6,400 & $(-)$ \\
\hline 25. & $\mathrm{~F}$ & Graves' & 30 & 41 & 15 & 60 & 0.76 & 400 & $(-)$ \\
\hline
\end{tabular}

ATMA: anti-thyromicrosome antibody, ND: not done, AITD: autoimmune thyroid disease, ICA: islet cell antibodies, $\mathrm{H}$ : onset is obscure. 


\section{Chikuba et al}

Table 2. Clinical Characteristics of Type 1 Diabetics with and without AITD

\begin{tabular}{lcc}
\hline & \multicolumn{2}{c}{ Type 1 diabetes mellitus } \\
\cline { 2 - 3 } & AITD (+) & AITD (-) \\
\hline No. & 25 & 32 \\
Sex (male/female) & $9 / 16$ & $9 / 23$ \\
Age at onset of IDDM & $28.1 \pm 13.6^{*}$ & $19.5 \pm 11.5$ \\
Duration (year) & $10.7 \pm 9.0$ & $9.9 \pm 8.8$ \\
Insulin requirement (U/kg/day) & $0.66 \pm 0.32$ & $0.71 \pm 0.35$ \\
Prevalence of ICA over 5 years & $59.1^{*}$ & 8.2 \\
\hline
\end{tabular}

$* p<0.01$ vs Type 1 diabetics without autoimmune thyroid disease.

diabetic patients with and without AITD. There were no significant differences between the two groups as far as insulin requirement and duration of diabetes were concerned. Among Type 1 diabetic patients with AITD, the age at onset of diabetes was $28.1 \pm 13.6$ years old, which was later than in those without AITD $(\mathrm{p}<0.01)$.

Figure 1 shows the prevalence of ICA based on the duration of diabetes in Type 1 diabetic patients with and without AITD. The prevalence of ICA in the newly diagnosed with and without AITD was 86.7 and 90.9

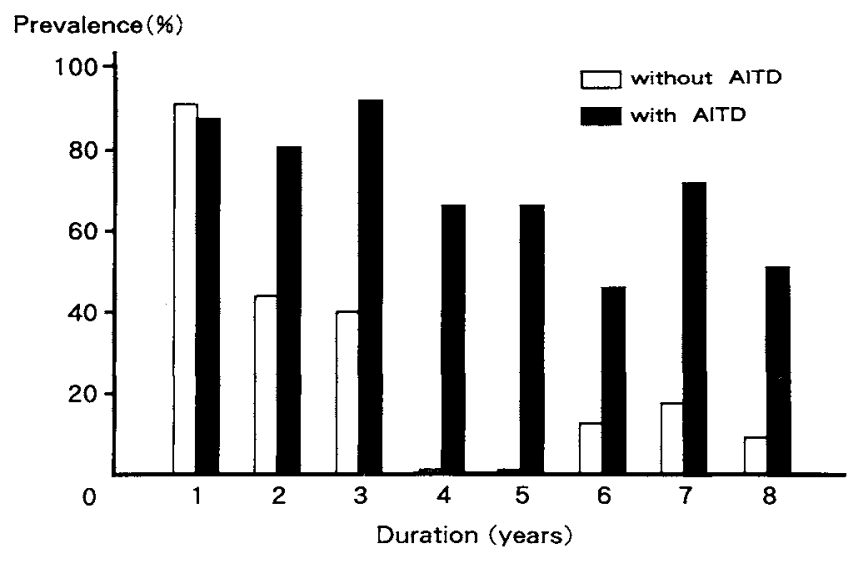

Fig. 1. Prevalence of islet cell antibodies based on the duration of diabetes in Type 1 diabetic patients with (closed bars) and without (open bars) AITD.

percent, respectively. These prevalence values were maintained from clinical diagnosis up to 3 years but decreased thereafter, the prevalence was about 67 percent at 4-5 years in Type 1 diabetic patients with AITD, while it declined progressively in Type 1 diabetic patients without AITD from the outset.

HLA-A, B, C and DR antigen frequencies were deter-

Table 3. Prevalence of HLA Antigens in Type 1 Diabetics with and without AITD

\begin{tabular}{lcccc}
\hline $\begin{array}{l}\text { HLA } \\
\text { Antigen }\end{array}$ & $\begin{array}{c}\text { Control }(\mathrm{n}=377) \\
\text { *8th JHW n }(\%)\end{array}$ & $\begin{array}{c}\text { Type 1 diabetics } \\
(\mathrm{n}=57) \mathrm{n}(\%)\end{array}$ & $\begin{array}{c}\text { with AITD } \\
(\mathrm{n}=25) \mathrm{n}(\%)\end{array}$ & $\begin{array}{c}\text { without AITD } \\
(\mathrm{n}=32) \mathrm{n}(\%)\end{array}$ \\
\hline Bw52 & $92(24.4)$ & $5(8.9)^{* * *}$ & $2(8.3)$ & $3(9.4)$ \\
Bw54 & $64(17.0)$ & $29(51.8)^{* * *}$ & $13(54.2)^{* * * *}$ & $16(50.0)^{* * * *}$ \\
DR2 & $130(34.5)$ & $3(5.3)^{* * *}$ & $1(4.0)^{* *}$ & $2(6.3)^{* * * *}$ \\
DR4 & $158(41.9)$ & $34(59.6)^{* *}$ & $12(48.0)$ & $22(68.8)^{* * *}$ \\
DR9 & $107(28.3)$ & $21(36.8)$ & $12(48.0)^{* *}$ & $9(28.1)$ \\
\hline
\end{tabular}

All comparisons were made against control subjects.

* 8th Japan HLA Workshop 13, AITD: Autoimmune thyroid disease, ** $\mathrm{p}<0.05$, ****: $\mathrm{p}<0.01$

Table 4. Autoantibodies in Patients with Japanese Type 1 Diabetes

\begin{tabular}{|c|c|c|c|c|c|c|}
\hline \multirow[t]{3}{*}{ * Auto $\mathrm{Ab}$} & \multirow{2}{*}{\multicolumn{2}{|c|}{ All paticnts }} & \multicolumn{4}{|c|}{ Diabctic paticnts } \\
\hline & & & \multicolumn{2}{|c|}{$\operatorname{AITD}(-)$} & \multicolumn{2}{|c|}{$\operatorname{AITD}(+)$} \\
\hline & $\begin{array}{c}\text { Male } \\
(\mathrm{n}=16) \\
\text { no }(\%)\end{array}$ & $\begin{array}{l}\text { Female } \\
(\mathrm{n}=39) \\
\text { no }(\%)\end{array}$ & $\begin{array}{c}\text { Malc } \\
(\mathrm{n}=8) \\
\text { no }(\%)\end{array}$ & $\begin{array}{c}\text { Femalc } \\
(\mathrm{n}=23) \\
\text { no }(\%)\end{array}$ & $\begin{array}{c}\text { Malc } \\
(\mathrm{n}=9) \\
\text { no }(\%)\end{array}$ & $\begin{array}{l}\text { Femalc } \\
(\mathrm{n}=16) \\
\text { no }(\%)\end{array}$ \\
\hline ATGA & $1(0)$ & $6(15.4)$ & $0(0)$ & $1(4.3)$ & $1(11.1)$ & $5(31.3)$ \\
\hline ATMA & $9(56.3)$ & $17(43.6)$ & $0(0)$ & $3(13.0)$ & $9(100.0)$ & $14(87.5)$ \\
\hline $\mathrm{AGA}$ & $0(0)$ & $0(0)$ & $0(0)$ & $0(0)$ & $0(0)$ & $0(0)$ \\
\hline $\mathrm{AAA}$ & $0(0)$ & $0(0)$ & $0(0)$ & $0(0)$ & $0(0)$ & $0(0)$ \\
\hline Any of 4 & $9(56.3)$ & $18(46.2)$ & $0(0)$ & $3(13.0)$ & $9(100.0)$ & $15(93.8)$ \\
\hline Auto Ab & & & & $L$ & & \\
\hline
\end{tabular}

* Auto Ab: auto antibodies other than ICA, ATGA: anti-thyroglobulin antibody, ATMA: antithyromicrosome antibody, AGA: antigastric antibody, AAA: anti-adrenal antibody, no: number of paticnts studicd. ${ }^{*} \mathrm{p}<0.01$. 
mined in 57 Type 1 diabetic patients with and without AITD and they were compared with 377 normal control subjects obtained from the data of the 8th Japan HLA Workshop (10). HLA antigen frequencies are presented in Table 3. The antigen frequencies of HLA-Bw54 and DR4 were significantly increased $(p<0.01, p<0.05)$ and those of HLA-Bw52, and DR2 were significantly decreased $(p<0.05, p<0.01)$. Patients were then classified into 2 groups according to complication with AITD. HLA-DR9 was increased in Type 1 diabetic patients with AITD $(\mathrm{p}<0.05)$, while HLA-DR4 was increased in Type 1 diabetic patients without AITD $(p<0.01)$, compared with normal controls. HLA-DR2 was decreased in Type 1 diabetic patients with and without AITD $(p<0.05, p<0.01)$. There was no association between HLA phenotypes and the incidence of persistent ICA in Type 1 diabetic patients with and without AITD.

The incidence of organ-specific autoantibodies in Type 1 diabetic patients is presented in Table 4. Of all the Type 1 diabetic patients, the incidence of autoantibodies was $56.3 \%(9 / 16)$ in male patients and $46.2 \%$ (18/39) in female patients. Antithyroidal microsomal antibody was detected in 3 of 31 Type 1 diabetic patients without AITD (13.0\%) and in 23 of 25 Type 1 diabetic patients with AITD $(92.0 \%)$. Antithyroglobulin antibody was detected in 6 of 25 Type 1 diabetic patients with AITD $(24.0 \%)$. Antiadrenal antibody and antigastric antibody were not detected in any of the patients studied.

\section{Discussion}

We classified Type 1 diabetic patients into those with AITD and those without AITD and compared these two groups. Type 1 diabetic patients with AITD were characterized by late onset of diabetes, persisting ICA and increased association with DR9, while those without AITD were characterized by early onset of diabetes and increased association with DR4. Our report demonstrated that there truly exists a heterogeneity in Type 1 diabetes mellitus in Japanese.

In Caucasians with Type 1 diabetes mellitus associated with autoimmune disease, aside from thyroid disease, association with Addison's disease and pernicious anemia have been reported (11). Hibi et al studied 1572 Japanese Type 1 diabetes mellitus (12). Thirty-three patients had AITD (2.10\%), and only one patient had pernicious anemia. No patient had Addison's disease. In Japanese patients with Type 1 diabetes mellitus, the coexisting autoimmune disease in most cases is AITD.

Irvine first suggested a heterogeneity in Type 1 diabetes mellitus in Caucasians (3). He reported that the association with other autoimmune diseases, late onset of diabetes, persistence of ICA and female predominance characterizes a certain clinical subgroup in Caucasians.

It has been thought that there is an autoimmune form of Type 1 diabetes mellitus which is associated with DR3 and another form associated with $\operatorname{DR} 4(13,14)$. The haplotype of DR3/B8 is related to Type 1 diabetes mellitus with autoimmune disease $(13,15)$. These patients have a higher incidence of autoimmune disease and autoantibodies, as compared to HLA-B15/DR4 in Caucasians $(16,17)$. On the other hand, Allen et al studied Type 1 diabetic patients with various thyroid abnormalities (18). Thyroid autoimmumity in Type 1 diabetes mellitus was associated with DR3 and DR4 to the same extent that Type 1 diabetes mellitus without thyroid disease is associated with these two antigens. Allen et al concluded that this thyroid autoimmunity was within the "Type 1 diabetes mellitus" syndrome.

In Japanese, HLA-DR9 antigen is reported to be increased in Type 1 diabetic patients with organ specific autoantibodies other than islet cell antibodies (19). DR9 was also associated with Type 1 diabetic patients with AITD. These results suggest that DR9 seems to be closely related to autoimmunity with Type 1 diabetes mellitus in Japanese.

Immunogenic background of Type 1 diabetes mellitus with AITD seems to be influenced by both HLA which is strongly associated with AITD and Type 1 diabetes mellitus. It was reported that HLA-Bw46 has strong association with AITD in Japanese patients (20). However, none of the Type 1 diabetic patients with AITD had HLA-Bw46. The clinical characteristics of AITD in patients with or without Type 1 diabetes mellitus are similar but perhaps the immunogenetic background of these two groups might be different.

We reported the prevalence of ICA in 316 patients with AITD (190 patients with Graves' disease and 126 patients with Hashimoto's thyroiditis) (21). The prevalence of ICA was 7.6\% (24/316). Among 24-ICA positive patients, $20(83 \%)$ had Type 1 diabetes. Betterle et al followed up 21 ICA-positive patients with organ-specific autoimmune disease for 7 years (22). Of the 21 patients, 10 patients were persistently seropositive for complement fixing ICA; seven patients developed diabetes. Only one patient developed diabetes among patients who were seronegative for complement fixing ICA and had low immunogloblin G ICA titres. A high frequency of HLA-DR3 and/or DR4 was found in patients who developed diabetes. In Type 1 diabetic patients with Graves' disease, Graves' disease preceded diabetes in 7 patients. These patients developed diabetes within 12 years after diagnosis of Graves' disease. Upon the onset of diabetes, all patients tested were seropositive for ICA. Of the 7 patients, $5(71.4 \%)$ had DR4 and/or DR9 antigens, which are associated with Type 1 diabetes mellitus. Thus, the presence of both persisting ICA and HLA-DR4 and/or DR9 in patients with organ-specific autoimmune disease, specifically Graves' disease, might appear to confer a high risk progression toward Type 1 diabetes in Japanese. On the other hand, Type 1 diabetes mellitus preceded Graves' disease in 6 patients. Four 


\section{Chikuba et al}

patients $(68 \%)$ had DR9. Autoantibodies to the thyroid gland and thyroid function should be, therefore, assayed in patients with Type 1 diabetes mellitus, especially in those with DR9.

\section{References}

1) Eberhardt MS, Wagener DK, Orchard TJ, ct al. HLA heterogeneity of insulin-dependent diabetes mellitus at diagnosis. The Pittsburgh IDDM study. Diabctes 34: 1247, 1985.

2) Ludvigsson J, Samuelsson U, Beauforts C, et al. HLA-DR3 is associated with a more slowly progressive form of Type 1 (insulindependent) diabetes. Diabetologia 29: 207, 1986.

3) Irvine WJ. Classification of diabetes mellitus. in: Immunology in Diabetes, Andereani D, Ed. Kimpton, London, 1984.

4) Farid NR, Simpson L, Moel P, et al. A study of human leukocyte D locus related antigens in Graves' disease. J Clin Invest 63: $108,1979$.

5) Weissel M, Hofer R, Zasmeta H, et al. HLA-DR and Hashimoto's thyroditis. Tissue Antigens 16: 256, 1980.

6) Sakurami K, Ueno Y, Nagaoka $K$, et al. HLA-DR specification in Japanese with juvenile-onset insulin-diabetes mellitus. Diabetes 31: $105,1982$.

7) Kida K, Mimura G, Kobayashi T. HLA haplotype study of Japanese Type 1 diabetes mellitus families. Second Asian Symposium on Childhood and Juvenile Diabctes Mcllitus, 1984.

8) Tcrasaki PI. Cytotoxicity Technique. in: Manual of Tissue Typing Techniques. Brand DR, Ray JG Eds. National Institutes of Health, Bethesda, 1970, p42.

9) Takahashi A, Tsujihata M, Yokota A, ct al. A new method of detection of islet cell antibodies (ICA) using peroxidase-labeled protein A, and incidence of ICA in type I (insulin-dependent) diabctes. Diabetologia 29: 378, 1986.

10) Fujii Y, Juji T, Kaibara N. Family study of HLA-A, B, C and DR in Japanesc. Jpn J Transplant 18: 189, 1983 (in Japanesc).

11) Irvine WJ, McCallum CJ, Gray RS, et al. Pancreatic islet-cell antibodies in diabetes mellitus correlated with the duration and type of diabetcs, coexistent autoimmune disease, and HLA type. Diabetes 26: 138, 1977.

12) Hibi I, Tanabe A, Isshiki G, et al. Juvenile onset insulin dependent diabetes in Japan. Japanese Clinical Endocrinology 30: 981, 1982 (in Japanese).

13) Shernthanner $G$, et al. The relationship between clinical, immunological and genetic factors in insulin-dependent diabetes. In: Kobberling J, Tattersall R, Eds. The Genetics of Diabetes Mellitus, Academic Press, New York, 1988, p99.

14) Rotter JI. The modes of inheritance of insulin-dependent diabetes mellitus. Am J Hum Genet 33: 835, 1981.

15) Farid NR, Larsen B, Payne R, et al. Polyglandular autoimmune disease and HLA. Tissuc Antigens 16: 23, 1980.

16) Rotter JI. The modes of inheritance of insulin-dependent diabetes mellitus or the genetics of IDDM, no longer a nightmare but still a headache. Am J Hum Genet 33: 835, 1981.

17) Bottazzo GF, Cudworth AG, Moul DJ, et al. Evidence for a primary autoimmune type of diabetes mellitus. Br Med $\mathrm{J}$ 2: 1253, 1978.

18) Allen DB, MacDonald MJ, Gottschall J, Hunter JB. Autoimmune thyroid phenomena are not evidence for human Lymphocyte Antigen-Genetic Heterogeneity in insulin-dependent diabetes. Am J Med Genet 33: 405, 1989

19) Kida K, Mimura G, Kobayashi T, et al. Immunogenetic heterogeneity in Type 1 (insulin-dependent) diabetes among JapaneseHLA antigen and organ-specific autoantibodies. Diabetologia 32: 34, 1989.

20) Shinagawa $\mathrm{H}$. The effect of HLA class II genes on the susceptibility to the autoimmmune thyroid disease. Fukuoka Acta Med 81: 97, 1990.

21) Yamaguchi $Y$, Chikuba N, Ueda $Y$, et al. Islet cell antibodies in patients with autoimmune thyroid disease. Diabetes 40: 319, 1991.

22) Betterle C, Presotto F, Pedini B, et al. Islet cell and insulin autoantibodies in organ-specific autoimmune patients. Their behavior and predictive value for the development of Type 1 (insulin-dependent) diabetes mellitus. A 10-ycar follow-up study. Diabetologia 30: 292, 1987. 